Review

\title{
The Endocytic Receptor Megalin and its Associated Proteins in Proximal Tubule Epithelial Cells
}

\author{
Shankhajit De ${ }^{1}$, Shoji Kuwahara ${ }^{2}$ and Akihiko Saito ${ }^{2, *}$
}

1 Division of Clinical Nephrology and Rheumatology, Niigata University Graduate School of Medical and Dental Sciences, 1-757 Asahimachi-dori, Chuo-ku, Niigata 951-8510, Japan; E-Mail: shankha1@med.niigata-u.ac.jp

2 Department of Applied Molecular Medicine, Niigata University Graduate School of Medical and Dental Sciences, 1-757 Asahimachi-dori, Chuo-ku, Niigata 951-8510, Japan;

E-Mail: kuwahara@med.niigata-u.ac.jp

* Author to whom correspondence should be addressed; E-Mail: akisaito@med.niigata-u.ac.jp; Tel.: +81-25-227-0915; Fax: +81-25-227-0914.

Received: 31 May 2014; in revised form: 23 June 2014 / Accepted: 1 July 2014 /

Published: 11 July 2014

\begin{abstract}
Receptor-mediated endocytosis in renal proximal tubule epithelial cells (PTECs) is important for the reabsorption and metabolization of proteins and other substances, including carrier-bound vitamins and trace elements, in glomerular filtrates. Impairment of this endocytic process results in the loss of such substances and development of proteinuria, which is an important clinical indicator of kidney diseases and is also a risk marker for cardiovascular disease. Megalin, a member of the low-density lipoprotein receptor gene family, is a multiligand receptor expressed in the apical membrane of PTECs and plays a central role in the endocytic process. Megalin interacts with various intracellular adaptor proteins for intracellular trafficking and cooperatively functions with other membrane molecules, including the cubilin-amnionless complex. Evidence suggests that megalin and the cubilin-amnionless complex are involved in the uptake of toxic substances into PTECs, which leads to the development of kidney disease. Studies of megalin and its associated molecules will be useful for future development of novel strategies for the diagnosis and treatment of kidney diseases.
\end{abstract}

Keywords: ARH; clathrin; ClC-5; cubilin; endocytosis; exosome; megalin; NHE3; trafficking 


\section{Introduction}

Endocytosis is a highly coordinated process that plays key roles in cell signaling and homeostasis [1]. In eukaryotes, endocytosis has long been thought of as a simple process by which cells internalize nutrients and membrane-associated molecules. Among the different types of endocytosis that have been identified to date, the most extensively studied and best characterized at the molecular level is clathrin-mediated endocytosis, which involves the internalization of cell-surface receptors and soluble molecules, including nutrients, from the extracellular fluid in clathrin-coated vesicles that bud off from the plasma membrane [2,3]. Although clathrin is the main coat component of the endocytic vesicles, a number of adaptor proteins are also involved in the initiation of vesicle budding, as clathrin is unable to interact directly with lipids and proteins in the plasma membrane [4]. These adaptor proteins are required to link clathrin with the membrane and are also able to specifically bind the endocytic cargo and ensure its uptake into clathrin-coated vesicles. After internalization, membrane receptors reach early endosome from where they are either recycled back to the plasma membrane or go to the late endosomes or multivesicular bodies (MVBs) from where they are destined to lysosomal degradation or go out of the cells in the form of exosomes. Exosomes are the nanovesicles of endocytic origin that are secreted into the extracellular space or body fluids whenever MVBs fuse with the cell membrane [5].

The receptor-mediated endocytosis and subsequent metabolization of proteins and nutrients is considered to be one of the most important functions of renal proximal tubular epithelial cells (PTECs). Receptor-mediated endocytosis requires the coordinated functioning of numerous proteins and signal transduction molecules. In particular, the membrane-associated endocytic receptor megalin and its associated proteins play a central role in the process.

Here, we summarize the current research progress on understanding the physiological as well as pathophysiological importance of megalin and its associated molecules in the function of PTECs.

\section{Structure and Function of Megalin}

Megalin (gp330) was first identified as a rat Heymann nephritis antigen [6,7]. After that, the gene encoding megalin was sequenced for both rats and humans, and was mapped to chromosome 2 in humans [8-10]. The megalin gene encodes an extremely large glycoprotein $(\approx 600 \mathrm{kDa})$, consisting of a large extracellular domain, small transmembrane domain, and intracellular domain, with high homology to members of the low-density lipoprotein (LDL) receptor superfamily [11]. As a common characteristic of the LDL superfamily, the extracellular domain of human megalin contains three kinds of repeats: (1) 36 cysteine-rich complement-type repeats comprising four clusters of ligand-binding domains; (2) 16 growth factor repeats that are separated by 8 YWTD-containing spacer regions and function in the $\mathrm{pH}$-dependent release of ligands in endosomal compartments; and (3) a single epidermal growth factor (EGF)-like repeat [12] (Figure 1). The large extracellular domain is followed by a single transmembrane region and a cytoplasmic domain that contains two highly conserved endocytic motifs (NPXY), which interact with adaptor proteins, and an NPXY-like motif (NQNY), which is involved in the apical sorting of megalin [13]. In addition to these motifs, megalin has several 
other motifs with unresolved function, such as SH3 and PDZ domains, and phosphorylation sites, which are likely involved in receptor-protein interactions $[8,9]$.

Figure 1. Megalin and its associated molecules in proximal tubule epithelial cells (PTECs). Among the various molecules present on the apical membrane of PTECs, megalin plays the central role in receptor-mediated endocytosis. Megalin also functions cooperatively with other membrane proteins, such as the cubilin-amnionless complex (CUBAM), NHE3, and $\mathrm{ClC5}$. NaPi-IIa is responsible for the renal uptake of Pi, whereas NHE3 and ClC5 are involved in further processing of endocytosed proteins. The neonatal receptor FcRn might be involved in the uptake and transcytosis of filtered albumin. A number of intracellular adaptor proteins, including ARH, Dab2, and GIPC, are involved in megalin trafficking. Reproduced with permission from [14]. Copyright 2011 Nova Science Publishers Inc.

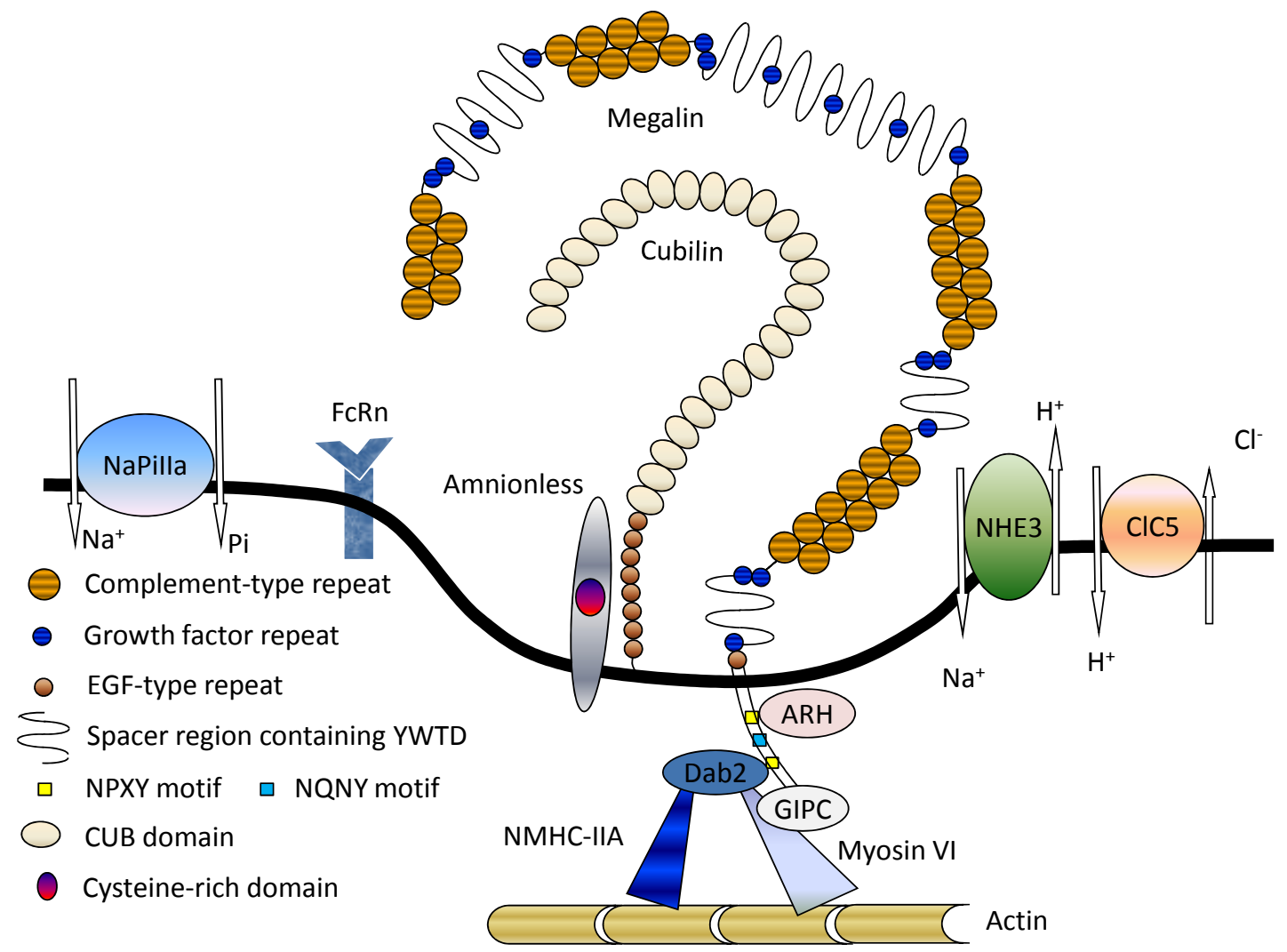

In the kidney, megalin is highly expressed in clathrin-coated pits and is also expressed at lower levels in PTEC microvilli $[15,16]$. A recent study revealed that human podocytes express megalin, which may require farther confirmation [17]. In addition to in the kidney, megalin is also expressed in different parts of the brain and central nervous system, including the brain capillaries, choroid plexus, spinal cord oligodendrocytes, astrocytes, and neurons [18-21]. Megalin is also present in intestinal brush border cells, gallbladder epithelial cells, thyroid follicular cells, ocular ciliary bodies, fallopian tubes, and uterus, and has been shown to perform various functions depending on the cell type [22-26].

Megalin plays a particular key role in the proximal tubular uptake of glomerular-filtered albumin and other low-molecular-weight-proteins. Consistent with this function, megalin knockout mice develop low-molecular-weight proteinuria and albuminuria [27]. Mutation of the megalin gene is 
associated with Donnai-Barrow syndrome, which is characterized by agenesis of the corpus callosum, congenital diaphragmatic hernia, facial dysmorphology, ocular anomalies, hearing loss, and developmental delay, and facio-oculo-acoustico-renal syndrome, which is characterized by low-molecular-weight proteinuria and albuminuria [28,29]. Megalin also interacts with sonic hedgehog and activates the associated pathway [30].

Several physiologically important substrates have been identified as megalin ligands including insulin [31], albumin [32], hemoglobin [33], vitamin D-binding protein (DBP) [34], retinol-binding protein (RBP) [35], $\beta_{2}$-microglobulin etc. [31,36]. In addition, a number of toxic substances, such as glycated proteins (AGEs) [37], myeloma light chain [38-40], and amino glycosides [41], also interact with megalin and undergo endocytosis, leading to PTEC injury. A complete list of megalin and cubilin ligands is given in the review by Christensen et al. [42].

\section{Megalin-Associated Molecules}

\subsection{Cubilin}

Cubilin, which was first identified as the receptor for intrinsic factor-vitamin $\mathrm{B}_{12}$, is co-expressed with megalin on apical epithelial cells $[43,44]$. Mutations in the cubilin-encoding gene cause hereditary megaloblastic anaemia 1 and Imerslund-Gräsbeck syndrome, which are associated with selective vitamin $\mathrm{B}_{12}$ malabsorption and proteinuria [45]. Recently, human and rat glomerular podocytes were also shown to express cubilin [46]. This $460 \mathrm{kDa}$ peripheral membrane glycoprotein lacks a transmembrane as well as intracellular domain, but anchored via its $\mathrm{NH}_{2}$ terminus to apical membranes in PTECs [47]. Cubilin consists of 27 CUB (complement components C1r/C1s, Uegf, and bone morphogenic protein 1) domain cluster preceded by 8 EGF repeats and a short, 110-amino-acid $\mathrm{N}$-terminal sequence [48]. Cubilin also functions as an endocytic receptor by binding to various ligands, including albumin [49], transferrin [50], DBP [51] etc., present in glomerular filtrates. As cubilin lacks an intracellular domain, it is thought to require interaction with megalin for proper functioning [52]. However, cubilin forms a functional complex with amnionless (AMN) named CUBAM, which is translocated to the plasma membrane and displays megalin-independent activity [53,54]. AMN is a $38-50 \mathrm{kDa}$ membrane protein that contains a 70 -amino-acid extracellular domain with a cysteine-rich domain and a cytoplasmic tail with 2 NPXY motifs [55]. AMN interacts with the EGF domains of cubilin to facilitate export of the CUBAM complex from the endoplasmic reticulum and for membrane attachment [56]. Recently, CUBAM-mediated protein reabsorption has been observed in Drosophila nephrocytes, which play a similar role in filtration as mammalian glomerular podocytes [57].

\section{2. $\mathrm{Na}^{+} / \mathrm{H}^{+}$Exchanger Isoform 3 (NHE3)}

Among the different isoforms of $\mathrm{Na}^{+} / \mathrm{H}^{+}$exchanger (NHE), NHE3 is predominantly found in PTECs, where it mediates the isotonic reabsorption of $\mathrm{NaCl}$ [58] and $\mathrm{NaHCO}_{3}$ [59], and the secretion of ammonium $[60,61]$. NHE3 ${ }^{-} /$mice exhibit decreased cortical bone mineral density and trabecular bone mass, demonstrating that epithelial NHE3 is necessary for renal and intestinal calcium reabsorption [62]. NHE3 is also involved in the reabsorption of citrate, amino acids, and oligopeptides 
from the urinary filtrate. Enhanced NHE3 activity may be responsible for elevated $\mathrm{Na}^{+}$retention and increased susceptibility to hypertension, as suggested by the enhanced $\mathrm{Na}^{+} / \mathrm{H}^{+}$exchange activity of NHE3 in PTECs of spontaneous hypertensive rats [63]. It is possible that a post-transcriptional event(s) leads to the increased expression and activity of NHE3, because mRNA levels were not elevated [63].

NHE3 interacts with megalin in the intermicrovillar clefts of PTECs [64,65]. The importance of NHE3 in $\mathrm{Na}^{+}$and acid-base homeostasis is exemplified by the hypovolemic hypotension and metabolic acidosis seen in $\mathrm{NHE}^{-} /$mice despite compensation by the distal nephron [66]. The abundance of NHE3 in PTECs, and its specific activity and subcellular localization are altered in rats with puromycin aminonucleoside (PAN)-induced nephrotic syndrome, suggesting a novel mechanism for the control of $\mathrm{Na}^{+} / \mathrm{H}^{+}$exchange in vivo [67]. In PTECs, insulin regulates the volume and acid-base balance through stimulation of NHE3 via yet undefined mechanisms, although the chronic effect of insulin is generally mediated by the classical PI3K-SGK1 pathway [68]. Endothelin increases acidification of acid-challenged animals and PTECs through enhanced activity of NHE3 [69]. After endocytosis with megalin, NHE3 is postulated to utilize the outward transvesicular $\mathrm{Na}^{+}$gradient of endocytic vesicles and early endosomes to drive the inward $\mathrm{H}^{+}$movement required for endosomal acidification, which is an important step in megalin trafficking [61].

\section{3. $2 \mathrm{Cl}^{-} / \mathrm{H}^{+}$-Exchanger $(\mathrm{ClC}-5)$}

ClC-5 is 746-amino-acid protein that was originally identified as a member of the voltage-gated chloride channel family [70], but later shown to function as an $\mathrm{H}^{+} / 2 \mathrm{Cl}^{-}$exchanger [71]. In the kidney, CIC-5 is highly expressed in PTECs, and $\alpha$ - and $\beta$-intercalated cells of collecting ducts [72]. Recently, it has been found that $\mathrm{ClC}-5$ is expressed in human podocytes [73]. Similar to its closely related homologs $\mathrm{ClC}-3$ and $\mathrm{ClC}-4, \mathrm{ClC}-5$ is primarily located on endosomal membranes; however, it is also expressed a low levels on plasma membranes [74,75]. In apical endosomes, ClC-5 functions in endosomal acidification in conjunction with electrogenic V-type $\mathrm{H}^{+}$-ATPases, where they are co-localized $[72,74]$. Evidence suggests that $\mathrm{ClC}-5$ provides an electric shunt for vesicular $\mathrm{H}^{+}$-ATPase (12-15), which is required for efficient endosomal acidification [76,77]. ClC-5 has a unique role in renal endocytosis among $\mathrm{ClC}$ exchangers and does not require PY-motif-dependent ubiquitylation [78]. ClC-5 and kinesin family member 3B (KIF3B), a heterotrimeric motor protein that facilitates fast anterograde translocation of membranous organelles, interact directly in polarized renal PTECs, which reabsorb proteins and solutes via the megalin and cubilin receptor-mediated endocytic pathway. The interaction between $\mathrm{ClC}-5$ and $\mathrm{KIF} 3 \mathrm{~B}$ in vivo leads to altered $\mathrm{ClC}-5$ cell-surface expression, microtubular transport, and endocytosis of $\mathrm{ClC}$-5-containing vesicles from the cell surface of polarized epithelial cells [79]. ClC-5 interacts with megalin in conjunction with a regulatory factor called $\mathrm{Na}^{+} / \mathrm{H}^{+}$ exchanger regulatory factor 2 (NHERF2), which acts as a scaffold for the two proteins [80]. The particular role of $\mathrm{ClC}-5$ in megalin and cubilin-mediated endocytosis was confirmed when in $\mathrm{ClC}-5$ knockout mice showed a reduced endocytosis of megalin/cubilin ligands, confirming that ClC-5 is required for the trafficking of megalin and cubilin in PTECs [81]. In contrast to the kidney, ClC-5 does not affect the expression or function of megalin in the thyroid gland, suggesting that megalin might be regulated differently in these two organs [82]. 
Mutations of the human gene encoding ClC-5 (CLCN5 gene) cause the X-linked disorder of the proximal tubules known as Dent's disease, which is characterized by low-molecular-weight proteinuria, hypercalciuria, nephrolithiasis, aminoaciduria, phosphaturia, and renal failure [83,84]. The pathology may result from defective fluid-phase and receptor-mediated endocytosis, and endosomal acidification, and/or reduced expression of megalin and cubilin in PTECs due to CLCN5 gene disruption $[85,86]$. Genomic analysis of a patient with Dent's disease and his family revealed a novel glycine-to-arginine transition mutation at the first nucleotide of codon 333 of CLCN5, which was associated with the markedly reduced and irregular expression of megalin and cubilin as well as adaptor protein Dab2 compared to a control subject [87]. Despite the identification of this mutation, Dent's disease exhibits genetic heterogeneity, with approximately $50 \%-60 \%$ of patients having CLCN5 mutations (Dent's disease 1), approximately 15\% harboring OCRL1 mutations (Dent's disease 2) and the remaining $25 \%-35 \%$ of patients having neither CLCN5 nor OCRL1 mutations, but possibly having defects in other genes [88]. Recently, an atypical Dent's disease phenotype was found to be due to co-inheritance of mutations in both CLCN5 and OCRL [89].

\subsection{Type IIa Sodium Phosphate Co-Transporter (NaPi-IIa)}

Renal reabsorption of phosphate $(\mathrm{Pi})$ is essential for maintaining plasma Pi homeostasis. Among the different types of $\mathrm{Na}^{+}$-dependent-Pi-co-transporters identified to date, type II is the functionally dominant type in renal PTECs [90]. The importance of this co-transporter was revealed in mice when targeted inactivation of the $N p t 2$ gene caused $70 \%$ less renal reabsorption of $\mathrm{Pi}$, leading to renal $\mathrm{Pi}$ wasting, hypercalciuria, and skeletal abnormalities. [91] The basic mechanism of Pi transport across the proximal tubular and small intestinal brush borders is nearly identical, but involves NaPi-IIa and $\mathrm{NaPi}$-IIb co-transporters in the kidney and gut, respectively [92]. Renal reabsorption of Pi is mediated by NaPi-IIa on PTECs and altered expression of this co-transporter in the brush border region leads to differences in renal Pi transport [93]. Parathyroid hormone (PTH) induces the inactivation of NaPi-IIa by promoting its endocytic retrieval and degradation, and it has been shown that megalin facilitates this process. Steady-state expression and PTH-driven inactivation of NaPi-IIa in PTECs is megalin dependent [94]. NaPi-IIa is co-expressed with NHE3 at apical microvilli; however, NHE3 is present within lipid rafts, whereas NaPi-IIa is predominantly located in nonrafts. In addition, kidney-specific inactivation of the megalin gene impairs trafficking of renal NaPi-IIa [94,95]. Analysis of the rat renal cortex revealed that $\mathrm{NaPi}$-IIa heterogeneously co-localizes with ezrin and megalin on the apical membrane of PTECs [96]. In response to hormones and a high dietary Pi content, NaPi-IIa is endocytosed and then either degraded in lysosomes or targeted to the trans-Golgi network (TGN), where it interacts with PIST (PDZ-domain protein interacting specifically with TC10), a TGN-resident PDZ-domain-containing protein [97]. Recently, fibroblast growth factor-23 (FGF23) was found to contribute to several hypophosphatemic disorders by reducing the expression of NaPi-IIa and NaPi-IIc in PTECs, as well as by lowering serum 1,25-dihydroxyvitamin D(3) levels [98].

\subsection{FcRn}

The neonatal $\mathrm{Fc}$ receptor for $\operatorname{IgG}(\mathrm{FcRn})$ is responsible for the transfer of passive humoral immunity from a mother to her fetus, and also performs diverse functions in various adult tissues [99]. 
FcRn is comprised of $\beta_{2}$-microglobulin and a membrane-anchored $\alpha$-chain related to major histocompatibility complex class I (MHC-I) [100,101]. The pH-dependent interaction between FcRn and albumin, which is stronger at lower $\mathrm{pH}$, is similar to that observed between FcRn and IgG and is critical for recycling albumin back into the circulation and avoiding cellular degradation, thereby prolonging its serum half-life [102]. Despite the overall similarity in the $\mathrm{pH}$-dependent binding mechanism with that of $\mathrm{IgG}$, albumin binds FcRn with a $1: 1$ stoichiometry and the interaction is hydrophobic in nature, suggesting that the FcRn-albumin interaction is distinct from FcRn-IgG binding [103]. In contrast, Studies of opossum kidney-derived cultured PTECs have demonstrated the FcRn-independent megalin- and/or cubilin-mediated uptake of FITC-conjugated IgG [104]. In the kidney, FcRn is expressed in podocytes and the brush border of PTECs [105]. In podocytes, FcRn is involved in the transcytosis of IgG around the slit diaphragm and into the urinary space, where it is then reabsorbed by FcRn in proximal tubules [106]. Recently, it was reported that $\mathrm{FcRn}^{-} /$mice have a lower $\mathrm{t}_{1 / 2}$ for albumin compared to wild-type mice, suggesting that renal $\mathrm{FcRn}$ reclaims albumin, but facilitates the loss of IgG from plasma protein pools [107]. Very recently, Tenten et al. proposed that the transcytosis of filtered albumin, as well as IgG, is FcRn dependent [108]; however, the physiological and pathophysiological role of the transtubular transport of filtered intact albumin is not yet known [109]. Further investigations are needed for a clearer understanding of the tubular processing of albumin by FcRn receptors.

\subsection{Intracellular Adaptor Proteins}

JIP1, JIP2, SEMCAP-1 (GIPC), ANKRA, PDS-95, MegBP, etc. are intracellular adaptor proteins that bind the cytoplasmic tail of megalin. Although these adaptor proteins are thought to facilitate endocytosis, their individual roles in megalin trafficking remain unclear [110-114]. Of these adaptor proteins, Dab2 and Autosomal Recessive Hypercholesterolemia (ARH) have been the most extensively studied and their roles in megalin trafficking are described below.

\section{Megalin Trafficking and Expression in PTECs}

\subsection{Role of Adaptor Proteins in Megalin Trafficking}

The complete mechanism and roles of megalin-associated adaptor proteins in megalin trafficking are largely unknown. In general, endocytosis of all LDL receptor family members require crucial NPXY signal in the cytoplasmic tail [115] and megalin also interacts with a number of proteins via its two conserved NPXY motifs present in its cytoplasmic domain. First NPXY motif of megalin binds to the phosphotyrosine-binding (PTB) domain of the ARH [116], and the second NPXY motif was shown to interact with the PTB domain of Dab2 [117] and both of them are considered to be clathrin-associated sorting proteins [118].

The adapter protein Dab2 and megalin mutually regulate each other's localization in PTECs. The expression of Dab2 in PTECs appears to be dependent on megalin or factors associated with megalin, while knockingout of the Dab2 gene decreases the level and alters the subcellular distribution of megalin in PTECs [119]. In addition to PTECs, Dab2 is also required for the endocytosis of megalin by visceral endoderm cells [120] and plays a major role in LDL receptor internalization in HeLa cells 
and fibroblasts [121]. Notably, Dab2 mediates internalization of LDL receptor family, but not transferrin receptor, and functions independently of ARH and AP-2 (classic clathrin adaptor protein) [121]. Dab2 and adapter protein GIPC facilitates binding of the megalin cytoplasmic tail to the reverse-direction molecular motor myosin VI, an interaction that is thought to be crucial for endocytosis in PTECs [122]. However, myosin VI knockingout mice show no significant renal manifestations or proteinuria [123]. In our studies, we identified another motor protein, nonmuscle myosin heavy chain IIA (NMHC-IIA) that binds to Dab2 and is involved in the endocytic process [124]. Genetic alterations to the NMHC-IIA gene are associated with the inherited human disease MYH9 disorder, which is characterized by giant platelets, thrombocytopenia, and granulocyte inclusions [125-127], thus indicating the importance of NMHC-IIA in maintaining normal kidney function. The involvement of NMHC-IIA in this disorder was verified in two genome-wide scan analyses of MYH9 patients [128,129]. More recently, it was demonstrated that protein kinase B (PKB)/Akt, which forms part of the endocytic machinery, mediates albumin uptake through interaction with Dab2 [130].

The potential role of ARH in LDL receptor function was first proposed when autosomal recessive hypercholesterolemia was found to be caused by mutations in the ARH gene [131]. ARH is a protein that binds to clathrin, AP-2, and the NPXY motif of megalin [132,133]. ARH facilitates the endocytosis and trafficking of megalin along the endocytic pathway [116], and also has been shown to associate with motor and centrosomal proteins, and to play a role in centrosomal assembly and cytokinesis [134]. In a recent study, it is reported that ARH is required for the trafficking of megalin from early endosomes to the endosomal recycling compartment by coupling with dynein; however, in the absence of ARH, megalin returns directly to the cell surface from early endosomes via the connecdenn2/Rab35 fast recycling pathway (Figure 2). ARH-mediated trafficking of megalin is necessary for $\gamma$-secretase-mediated cleavage of megalin and release of a tail fragment that mediates transcriptional repression of megalin mRNA [135]. In addition, ARH cooperates with epithelial cell-specific clathrin adaptor protein AP-1B in the basolateral exocytosis of LDL receptor family from recycling endosomes in polarized epithelial cells [136].

The adaptor proteins ARH and Dab2 are not only crucial for megalin trafficking, but are also essential for endocytosis of the endocytic receptor CUBAM. Like the LDL receptor superfamily, cubilin contains a ligand-binding domain while AMN provides membrane anchorage and potential endocytic capacity via two NPXY signals via ARH and Dab2 [137]. Future studies are required to elucidate the complete set of interactions and adapter proteins underlying megalin trafficking.

\subsection{Megalin-Expressing Exosomes}

Although exosomes have been described since 1981, they received relatively little attention from the scientific community until the past decade. Shortly after the discovery of exosomes, an electron microscopic study of sheep erythrocytes reported that exocytosis results in vesicles of approximately 50-nm in size [138]. Exosomes are membrane vesicles of endocytic origin and are released by different types of cells upon the fusion of multivesicular bodies with the plasma membrane [139] and should not be confused with microvesicles, which bud directly from the plasma membrane into the extracellular space upon certain stimulation [140]. Exosomes range in size from 30-120 nm, [138] and are released by different cell types under physiological, as well as pathophysiological, conditions [141]. Because 
exosomes can contain various cellular components, including proteins, mRNAs, and miRNAs, and are produced by one cell but taken up by other cells, they are thought to represent a new mode of intercellular communication that can modulate diverse physiological and pathophysiological phenomenon, such as angiogenesis, immunoreactions, and cell proliferation [142,143].

Figure 2. Megalin-mediated endocytosis and megalin trafficking. The plasma membranes start to invaginate and at last bud off during endocytic internalization and reach early endosomes, where the decision for further ligand processing is made depending on the cargo content. In the absence of ARH, megalin is recycled back to the plasma membrane via the early recycling pathway, whereas in the presence of $\mathrm{ARH}$, megalin is recycled back to the membrane via the late recycling pathway. Depending on the specific protein interactions and domain-based sorting processes, early endosomes may also be directed to late endosomes, which then matures into a late endosomal compartment and forms multivesicular bodies. When multivesicular bodies come into contact with the plasma membrane, their contents are secreted in the form of exosomes. Megalin ligands may be subjected to lysosomal degradation and the metabolized ligands then undergo basolateral transcytosis. Megalin also undergoes regulated intramembrane proteolysis (RIP) and is shedded from plasma membrane.

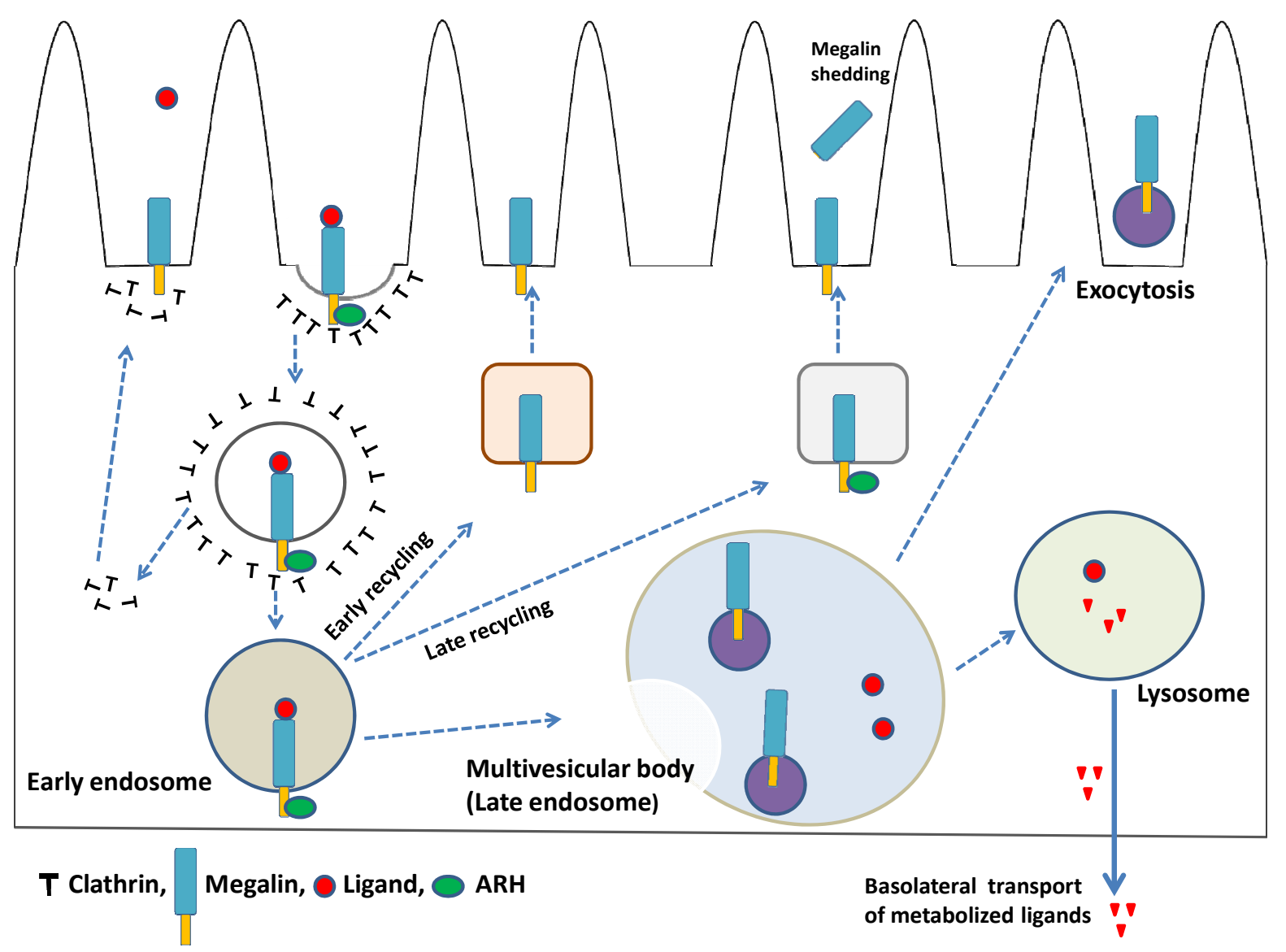

Urinary exosomes, which are released by epithelial cells facing the urinary space, are considered to be a promising source of molecular markers for renal dysfunction and structural pathology [144]. Proteomics studies have revealed that urinary exosomes contain the endocytic receptors megalin and 
cubilin, in addition to several other important markers and transporter proteins, such as NHE3, sodium-glucose co-transporter 1, aquaporin-1 from proximal tubules, sodium-potassium-chloride co-transporter 2 from the thick ascending limb, and thiazide-sensitive sodium-chloride co-transporter from the distal convoluted tubule $[145,146]$. Thus, the study of exosomal proteins, as well as associated mRNAs and miRNAs, is expected to provide greater understanding of the molecular mechanisms of diseases and identify related biomarkers [147]. A schematic diagram of megalin-expressing exosomes from PTECs is shown in Figure 2.

\subsection{Megalin Expression and Regulated Intramembrane Proteolysis (RIP)}

TGF- $\beta$ was found to downregulate the cellular expression of megalin [148], whereas insulin and high-concentration glucose $(17.5 \mathrm{mM})$ upregulate megalin expression in opossum kidney-derived cultured PTECs [148]. Megalin is also downregulated by angiotensin II and competitive cross-talk occurs between anigotensin II type 1 receptor and insulin-induce megalin expression, which serve as a counterbalancing mechanism for the regulation of megalin expression and function in PTECs [149]. We also demonstrated that low levels of lipopolysaccharide initiate the TNF- $\alpha$-ERK1/2 signaling pathway, which is involved in the downregulation of megalin expression in cultured PTECs [150]. In contrast, peroxisome proliferator-activated receptors (PPARs) $\alpha$ and $\gamma$, which are transcription factors belonging to the nuclear receptor superfamily, and PPAR $\alpha$ and $\gamma$ agonists positively control megalin expression [151]. Bardoxolone methyl, a potent activator of the nuclear factor erythroid 2-related factor 2 (Nrf2), also decreases megalin expression, but not cubilin expression, in monkey PTECs [152]. However, further studies are required to understand the molecular mechanisms related to megalin expression in the presence of bardoxolone methyl.

Similar to other large transmembrane proteins, such as notch receptors, megalin also undergoes RIP, which produces the megalin intracellular domain (MICD). In this process, megalin is subjected to PKC-regulated, metalloprotease-mediated ectodomain shedding, producing a membrane-bound, 35-40 kDa COOH-terminal fragment, which is further processed by $\gamma$-secretase to produce a soluble MICD [153]. In cultured opossum kidney-derived PTECs, megalin COOH-terminal domains regulate expression of the megalin gene, as well as NHE3 [154]. Notably, however, the soluble intracellular domain of megalin appears to have no role in the regulation of gene expression in PTECs in vivo [155].

\section{Megalin-Mediated PTEC Injury}

Overloaded endocytosis in PTECs might cause tubulointerstitial injury in various pathogenic conditions. Megalin has been identified as the key molecule in the initiation of the pathogenic process of endocytosis-mediated PTEC injury [156]. In particular, albumin overload in PTECs induces oxidative stress, the upregulation of stress-related genes [157], and activation of NF-k $\beta$, which is responsible for enhancing the synthesis of the inflammatory chemokine RANTES and production reactive oxygen species that serve as secondary messengers of NF-k $\beta$ activation [158]. Metabolically overloaded PTECs are also activated to express a number of pro-inflammatory cytokines, such as MCP1 and TNF $\alpha$ and leading to apoptosis [158] or epithelial-mesenchymal transition (EMT) $[159,160]$. In diabetic patients, megalin mediates the endocytosis of glomerular-filtered AGEs by PTECs [37,161], leading to cellular toxicity [162]. The intake of AGEs might also overload megalin and lower 
cobalamin uptake, which might cause the intracellular cobalamin deficiency that is often observed renal dysfunction, diabetes, and aging. Shedding of the megalin and transcobalamin receptors under glycated conditions has also been observed [163]. Megalin-mediated endocytosis of myeloma light chain into PTECs initiates a number of inflammatory processes, resulting in cell toxicity and EMT which are the underlying cause of chronic tubulointerstitial diseases and acute renal injury in myeloma [164-166]. Receptor-associated protein (RAP), which is the ligand as well as chaperone protein of megalin, can block internalization and toxicity of myeloma light chain in cultured PTECs [40]. Taken together, this evidence clearly demonstrates that megalin plays a critical role in the normal physiology, as well as pathophysiology, of PTECs.

We have established an ELISA system to quantitate full length and ectodomain forms of megalin in human urine, which will be useful for the clinical evaluation of PTEC injury [167]. Further studies are needed to elucidate the complete molecular mechanism and develop strategies for preventing PTEC damage.

\section{Conclusions}

Megalin is an endocytic receptor involved in the reabsorption of nutrients, carrier-bound vitamins, and trace elements from glomerular filtrates via interaction with various molecules in PTECs. This receptor also mediates the renal uptake of pathological substances or the overloaded endocytosis that can cause cellular damage. Megalin-mediated signal transduction might also be involved in this process. Further studies are required to elucidate the complete molecular mechanism underlying tubulointerstitial injury and develop novel strategies for preventing PTEC damage and diagnosing and treating different kidney diseases.

\section{Acknowledgments}

This work was supported by Grants-in-Aid for Scientific Research from the Ministry of Education, Science, and Culture of Japan to A.S. (26461216).

\section{Author Contributions}

S.D., S.K. and A.S. wrote the paper.

\section{Conflicts of Interest}

The authors declare no conflict of interest.

\section{References}

1. Evans, P.R.; Owen, D.J. Endocytosis and vesicle trafficking. Curr. Opin. Struct. Biol. 2002, 12, 814-821.

2. Scita, G.; di Fiore, P.P. The endocytic matrix. Nature 2010, 463, 464-473.

3. Taylor, M.J.; Perrais, D.; Merrifield, C.J. A high precision survey of the molecular dynamics of mammalian clathrin-mediated endocytosis. PLoS Biol. 2011, 9, e1000604:1-e1000604:23. 
4. Maldonado-Báez, L.; Wendland, B. Endocytic adaptors: Recruiters, coordinators and regulators. Trends Cell Biol. 2006, 16, 505-513.

5. Denzer, K.; Kleijmeer, M.J.; Heijnen, H.F.; Stoorvogel, W.; Geuze, H.J. Exosome: From internal vesicle of the multivesicular body to intercellular signaling device. J. Cell. Sci. 2000, 113, 3365-3374.

6. Kerjaschki, D.; Farquhar, M.G. The pathogenic antigen of Heymann nephritis is a membrane glycoprotein of the renal proximal tubule brush border. Proc. Natl. Acad. Sci. USA 1982, 79, 5557-5561.

7. Kerjaschki, D.; Farquhar, M.G. Immunocytochemical localization of the Heymann nephritis antigen (GP330) in glomerular epithelial cells of normal Lewis rats. J. Exp. Med. 1983, 157, 667-686.

8. Saito, A.; Pietromonaco, S.; Loo, A.K.; Farquhar, M.G. Complete cloning and sequencing of rat gp330/'megalin' a distinctive member of the low density lipoprotein receptor gene family. Proc. Natl. Acad. Sci. USA 1994, 91, 9725-9729.

9. Hjälm, G.; Murray, E.; Crumley, G.; Harazim, W.; Lundgren, S.; Onyango, I.; Ek, B.; Larsson, M.; Juhlin, C.; Hellman, P.; et al. Cloning and sequencing of human gp330, a $\mathrm{Ca}^{2+}$-binding receptor with potential intracellular signaling properties. Eur. J. Biochem. 1996, 239, 132-137.

10. Xia, Y.R.; Bachinsky, D.R.; Smith, J.A.; McCluskey, R.T.; Warden, C.H.; Lusis, A.J. Mapping of the glycoprotein 330 (Gp330) gene to mouse chromosome 2. Genomics 1993, 17, 780-781.

11. Raychowdhury, R.; Niles, J.L.; McCluskey, R.T.; Smith, J.A. Autoimmune target in Heymann nephritis is a glycoprotein with homology to the LDL receptor. Science 1989, 244, 1163-1165.

12. Davis, C.G.; Goldstein, J.L.; Sudhof, T.C.; Anderson, R.G.; Russell, D.W.; Brown, M.S. Acid-dependent ligand dissociation and recycling of LDL receptor mediated by growth factor homology region. Nature 1987, 326, 760-765.

13. Takeda, T.; Yamazaki, H.; Farquhar, M.G. Identification of an apical sorting determinant in the cytoplasmic tail of megalin. Am. J. Physiol. Cell. Physiol. 2003, 284, C1105-C1113.

14. Saito, A.; Sato, H.; Iino, N.; Takeda, T. Physiology and Pathophysiology of Megalin-Mediated Endocytosis in Renal Proximal Tubule Cells. In Advances in Medicine and Biology; Berhardt, L.V., Ed.; Nova Science Publishers, Inc.: Hauppauge, NY, USA, 2011; Volume 14, pp. 169-184.

15. Verroust, P.J.; Kozyraki, R.; Hammond, T.G.; Moestrup, S.K.; Christensen, E.I. Physiopathologic role of cubilin and megalin. Adv. Nephrol. Necker. Hosp. 2000, 30, 127-145.

16. Christensen, E.I.; Verroust, P.J.; Nielsen, R. Receptor mediated endocytosis in renal proximal tubule. Pflugers. Arch. 2009, 458, 1039-1048.

17. Prabakaran, T.; Nielsen, R.; Larsen, J.V.; Sørensen, S.S.; Feldt-Rasmussen, U.; Saleem, M.A.; Petersen, C.M.; Verroust, P.J.; Christensen, E.I. Receptor-mediated endocytosis of $\alpha$-galactosidase A in human podocytes in Fabry disease. Nephrol. Dial. Transplant. 2012, 27, 3156-3159.

18. Chun, J.T.; Wang, L.; Pasinetti, G.M.; Finch, C.E.; Zlokovic, B.V. Glycoprotein 330/megalin (LRP-2) has low prevalence as mRNA and protein in brain microvessels and choroid plexus. Exp. Neurol. 1999, 157, 194-201. 
19. Wicher, G.; Larsson, M.; Svenningsen, A.F.; Gyllencreutz, E.; Rask, L.; Aldskogius, H. Low density lipoprotein receptor-related protein-2/megalin is expressed in oligodendrocytes in the mouse spinal cord white matter. J. Neurosci. Res. 2006, 83, 864-873.

20. Bento-Abreu, A.; Velasco, A.; Polo-Hernández, E.; Pérez-Reyes, P.L.; Tabernero, A.; Medina, J.M. Megalin is a receptor for albumin in astrocytes and is required for the synthesis of the neurotrophic factor oleic acid. J. Neurochem. 2008, 106, 1149-1159.

21. Chung, R.S.; Penkowa, M.; Dittmann, J.; King, C.E.; Bartlett, C.; Asmussen, J.W.; Hidalgo, J.; Carrasco, J.; Leung, Y.K.; Walker, A.K.; et al. Redefining the role of metallothionein within the injured brain: Extracellular metallothioneins play an important role in the astrocyte-neuron response to injury. J. Biol. Chem. 2008, 283, 15349-15358.

22. Yammani, R.R.; Seetharam, S.; Seetharam, B. Cubilin and megalin expression and their interaction in the rat intestine: Effect of thyroidectomy. Am. J. Physiol. Endocrinol. Metab. 2001, 281, E900-E907.

23. Erranz, B.; Miquel, J.F.; Argraves, W.S.; Barth, J.L.; Pimentel, F.; Marzolo, M.P. Megalin and cubilin expression in gallbladder epithelium and regulation by bile acids. J. Lipid Res. 2004, 45, 2185-2198.

24. Lundgren, S.; Hjälm, G.; Hellman, P.; Ek, B.; Juhlin, C.; Rastad, J.; Klareskog, L.; Åkerström, G.; Rask, L. A protein involved in calcium sensing of the human parathyroid and placental cytotrophoblast cells belonging to the LDL-receptor superfamily. Exp. Cell Res. 1994, 212, 344-350.

25. Lundgren, S.; Carling, T.; Hjälm, G.; Juhlin, C.; Rastad, J.; Pihlgren, U.; Rask, L.; Akerström, G.; Hellman, P. Tissue distribution of human gp330/megalin, a putative $\mathrm{Ca}^{2+}$-sensing protein. J. Histochem. Cytochem. 1997, 45, 383-392.

26. Argraves, W.S.; Morales, C.R. Immunolocalization of cubilin, megalin, apolipoprotein J, and apolipoprotein A-I in the uterus and oviduct. Mol. Reprod. Dev. 2004, 69, 419-427.

27. Leheste, J.R.; Rolinski, B.; Vorum, H.; Hilpert, J.; Nykjaer, A.; Jacobsen, C.; Aucouturier, P.; Moskaug, J.O.; Otto, A.; Christensen, E.I.; et al. Megalin knockout mice as an animal model of low molecular weight proteinuria. Am. J. Pathol. 1999, 155, 1361-1370.

28. Kantarci, S.; Al-Gazali, L.; Hill, R.S.; Donnai, D.; Black, G.C.; Bieth, E.; Chassaing, N.; Lacombe, D.; Devriendt, K.; et al. Mutations in LRP2, which encodes the multiligand receptor megalin, cause Donnai-Barrow and facio-oculo-acoustico-renal syndromes. Nat. Genet. 2007, 39, 957-959.

29. Pober, B.R.; Longoni, M.; Noonan, K.M. A Review of Donnai-Barrow and Facio-oculoacousticorenal (DB/FOAR) Syndrome: Clinical features and differential diagnosis. Birth Defects Res. A Clin. Mol. Teratol. 2009, 85, 76-81.

30. McCarthy, R.A.; Barth, J.L.; Chintalapudi, M.R.; Knaak, C.; Argraves, W.S. Megalin functions as an endocytic sonic hedgehog receptor. J. Biol. Chem. 2002, 277, 25660-25667.

31. Orlando, R.A.; Rader, K.; Authier, F.; Yamazaki, H.; Posner, B.I.; Bergeron, J.J.; Farquhar, M.G. Megalin is an endocytic receptor for insulin. J. Am. Soc. Nephrol. 1998, 9, 1759-1766.

32. Cui, S.; Verroust, P.J.; Moestrup, S.K.; Christensen, E.I. Megalin/gp330 mediates uptake of albumin in renal proximal tuble. Am. J. Physiol. Renal. Physiol. 1996, 271, F900-F907. 
33. Gburek, J.; Verroust, P.J.; Willnow, T.E.; Fyfe, J.C.; Nowacki, W.; Jacobsen, C.; Moestrup, S.K.; Christensen, E.I. Megalin and cubilin are endocytic receptors involved in renal clearance of hemoglobin. J. Am. Soc. Nephrol. 2002, 13, 423-430.

34. Nykjaer, A.; Dragun, D.; Walther, D.; Vorum, H.; Jacobsen, C.; Herz, J.; Melsen, F.; Christensen, E.I.; Willnow, T.E. An endocytic pathway essential for renal uptake and activation of the steroid 25-(OH) vitamin D3. Cell 1999, 96, 507-515.

35. Christensen, E.I.; Moskaug, J.O.; Vorum, H.; Jacobsen, C.; Gundersen, T.E.; Nykjaer, A.; Blomhoff, R.; Willnow, T.E.; Moestrup, S.K. Evidence for an essential role of megalin in transepithelial transport of retinol. J. Am. Soc. Nephrol. 1999, 10, 685-695.

36. Saito, A.; Kazama, J.J.; Iino, N.; Cho, K.; Sato, N.; Yamazaki, H.; Oyama, Y.; Takeda, T.; Orlando, R.A.; Shimizu, F. Bioengineered implantation of megalin-expressing cells: A potential intracorporeal therapeutic model for uremic toxin protein clearance in renal failure. $J$. Am. Soc. Nephrol. 2003, 14, 2025-2032.

37. Saito, A.; Nagai, R.; Tanuma, A.; Hama, H.; Cho, K.; Takeda, T.; Yoshida, Y.; Toda, T.; Shimizu, F.; Horiuchi, S.; Gejyo, F. Role of megalin in endocytosis of advanced glycation end products: Implications for a novel protein binding to both megalin and advanced glycation end products. J. Am. Soc. Nephrol. 2003, 14, 1123-1131.

38. Batuman, V.; Guan, S. Receptor-mediated endocytosis of immunoglobulin light chains by renal proximal tubule cells. Am. J. Physiol. Renal Physiol. 1997, 272, F521-F530.

39. Klassen, R.B.; Allen, P.L.; Batuman, V.; Crenshaw, K.; Hammond, T.G. Light chains are a ligand for megalin. J. Appl. Physiol. 2005, 98, 257-263.

40. Sengul, S.; Erturk, S.; Khan, A.M.; Batuman, V. Receptor-Associated Protein blocks internalization and cytotoxicity of Myeloma Light Chain in cultured human proximal tubular cells. PLoS One 2013, 8, e70276:1-e70276:8.

41. Moestrup, S.K.; Cui, S.; Vorum, H.; Bregengård, C.; Bjørn, S.E.; Norris, K.; Gliemann, J.; Christensen, E.I. Evidence that epithelial glycoprotein 330/megalin mediates uptake of polybasic drugs. J. Clin. Invest. 1995, 96, 1404-1413.

42. Christensen, E.I.; Birn, H.; Storm, T.; Weyer, K.; Nielsen, R. Endocytic receptors in the renal proximal tubule. Physiology 2012, 27, 223-236.

43. Seetharam, B.; Levine, J.S.; Ramsey, M.; Alpers, D.H. Purification, properties, and immunochemical localization of a receptor for intrinsic factor-cobalamin complex in the rat kidney. J. Biol. Chem. 1988, 263, 4443-4449.

44. Seetharam, B.; Christensen, E.I.; Moestrup, S.K.; Hammond, T.G.; Verroust, P.J. Identification of rat yolk sac target protein of teratogenic antibodies, gp280, as intrinsic factor-cobalamin receptor. J. Clin. Invest. 1997, 99, 2317-2322.

45. Aminoff, M.; Carter, J.E.; Chadwick, R.B.; Johnson, C.; Gräsbeck, R.; Abdelaal, M.A.; Broch, H.; Jenner, L.B.; Verroust, P.J.; Moestrup, S.K.; et al. Mutations in CUBN, encoding the intrinsic factor-vitamin B12 receptor, cubilin, cause hereditary megaloblastic anaemia 1. Nat. Genet. 1999, 21, 309-313.

46. Prabakaran, T.; Christensen, E.I.; Nielsen, R.; Verroust, P.J. Cubilin is expressed in rat and human glomerular podocytes. PLoS One 2011, 6, e25065:1-e25065:11. 
47. Kristiansen, M.; Kozyraki, R.; Jacobsen, C.; Nexø, E.; Verroust, P.J.; Moestrup, S.K. Molecular dissection of the intrinsic factor-vitamin B12 receptor, cubilin, discloses regions important for membrane association and ligand binding. J. Biol. Chem. 1999, 274, 20540-20544.

48. Kozyraki, R.; Kristiansen, M.; Silahtaroglu, A.; Hansen, C.; Jacobsen, C.; Tommerup, N.; Verroust, P.J.; Moestrup, S.K. The human intrinsic factor-vitamin B12 receptor, cubilin: Molecular characterization and chromosomal mapping of the gene to $10 \mathrm{p}$ within the autosomal recessive megaloblastic anemia (MGA1) region. Blood 1998, 91, 3593-3600.

49. Birn, H.; Fyfe, J.C.; Jacobsen, C.; Mounier, F.; Verroust, P.J.; Orskov, H.; Willnow, T.E.; Moestrup, S.K.; Christensen, E.I. Cubilin is an albumin binding protein important for renal tubular albumin reabsorption. J. Clin. Invest. 2000, 105, 1353-1361.

50. Kozyraki, R.; Fyfe, J.; Verroust, P.J.; Jacobsen, C.; Dautry-Varsat, A.; Gburek, J.; Willnow, T.E.; Christensen, E.I.; Moestrup, S.K. Megalin-dependent cubilin-mediated endocytosis is a major pathway for the apical uptake of transferrin in polarized epithelia. Proc. Natl. Acad. Sci. USA 2001, 98, 12491-12496.

51. Nykjaer, A.; Fyfe, J.C.; Kozyraki, R.; Leheste, J.R.; Jacobsen, C.; Nielsen, M.S.; Verroust, P.J.; Aminoff, M.; de la Chapelle, A.; Moestrup, S.K.; et al. Cubilin dysfunction causes abnormal metabolism of the steroid hormone $25(\mathrm{OH})$ vitamin D(3). Proc. Natl. Acad. Sci. USA 2001, 98, 13895-13900.

52. Yammani, R.R.; Seetharam, S.; Seetharam, B. Identification and characterization of two distinct ligand binding regions of cubilin. J. Biol. Chem. 2001, 276, 44777-44784.

53. Fyfe, J.C.; Madsen, M.; Højrup, P.; Christensen, E.I.; Tanner, S.M.; de la Chapelle, A.; He, Q.; Moestrup, S.K. The functional cobalamin (vitamin B12)-intrinsic factor receptor is a novel complex of cubilin and amnionless. Blood 2004, 103, 1573-1579.

54. Coudroy, G.; Gburek, J.; Kozyraki, R.; Madsen, M.; Trugnan, G.; Moestrup, S.K.; Verroust, P.J.; Maurice, M. Contribution of cubilin and amnionless to processing and membrane targeting of cubilin-amnionless complex. J. Am. Soc. Nephrol. 2005, 16, 2330-2337.

55. Kalantry, S.; Manning, S.; Haub, O.; Tomihara-Newberger, C.; Lee, H.G.; Fangman, J.; Disteche, C.M.; Manova, K.; Lacy, E. The amnionless gene, essential for mouse gastrulation, encodes a visceral endoderm-specific protein with an extracellular cysteine-rich domain. Nat. Genet. 2001, 27, 412-416.

56. He, Q.; Madsen, M.; Kilkenney, A.; Gregory, B.; Christensen, E.I.; Vorum, H.; Højrup, P.; Schäffer, A.A.; Kirkness, E.F.; et al. Amnionless function is required for cubilin brush-border expression and intrinsic factor-cobalamin (vitamin B12) absorption in vivo. Blood 2005, 106, $1447-1453$.

57. Zhang, F.; Zhao, Y.; Chao, Y.; Muir, K.; Han, Z. Cubilin and amnionless mediate protein reabsorption in Drosophila nephrocytes. J. Am. Soc. Nephrol. 2013, 24, 209-216.

58. Preisig, P.A; Rector, F.C., Jr. Role of $\mathrm{Na}^{+}-\mathrm{H}^{+}$antiport in rat proximal tubule $\mathrm{NaCl}$ absorption. Am. J. Physiol. Renal Physiol. 1988, 255, F461-F465.

59. Preisig, P.A.; Ives, H.E.; Cragoe, E.J., Jr.; Alpern, R.J.; Rector, F.C., Jr. Role of the $\mathrm{Na}^{+} / \mathrm{H}^{+}$ antiporter in rat proximal tubule bicarbonate absorption. J. Clin. Invest. 1987, 80, 970-978.

60. Nagami, G.T. Luminal secretion of ammonia in the mouse proximal tubule perfused in vitro. J. Clin. Invest. 1988, 81, 159-164. 
61. Bobulescu, I.A.; Moe, O.W. Luminal $\mathrm{Na}^{+} / \mathrm{H}^{+}$exchange in the proximal tubule. Pflugers. Arch. 2009, 458, 5-21.

62. Pan, W.; Borovac, J.; Spicer, Z.; Hoenderop, J.G.; Bindels, R.J.; Shull, G.E.; Doschak, M.R.; Cordat, E.; Alexander, R.T. The epithelial sodium/proton exchanger, NHE3, is necessary for renal and intestinal calcium (re)absorption. Am. J. Physiol. Renal Physiol. 2012, 302, F943-F956.

63. LaPointe, MS.; Sodhi, C.; Sahai, A.; Batlle, D. $\mathrm{Na}^{+} / \mathrm{H}^{+}$exchange activity and NHE-3 expression in renal tubules from the spontaneously hypertensive rat. Kidney Int. 2002, 62, 157-165.

64. Biemesderfer, D.; Nagy, T.; DeGray, B.; Aronson, P.S. Specific association of megalin and the $\mathrm{Na}^{+} / \mathrm{H}^{+}$exchanger isoform NHE3 in the proximal tubule. J. Biol. Chem. 1999, 274, 17518-17524.

65. Biemesderfer, D.; DeGray, B.; Aronson, P.S. Active (9.6 s) and inactive (21 s) oligomers of NHE3 in microdomains of the renal brush border. J. Biol. Chem. 2001, 276, 10161-10167.

66. Schultheis, P.J.; Clarke, L.L.; Meneton, P.; Miller, M.L.; Soleimani, M.; Gawenis, L.R.; Riddle, T.M.; Duffy, J.J.; Doetschman, T.; Wang, T.; et al. Renal and intestinal absorptive defects in mice lacking the NHE3 $\mathrm{Na}^{+} / \mathrm{H}^{+}$exchanger. Nat. Genet. 1998, 19, 282-285.

67. Besse-Eschmann, V.; Klisic, J.; Nief, V.; Le Hir, M.; Kaissling, B.; Ambühl, P.M. Regulation of the proximal tubular sodium/proton exchanger NHE3 in rats with Puromycin Aminonucleoside (PAN)-induced nephrotic syndrome. J. Am. Soc. Nephrol. 2002, 13, 2199-2206.

68. Fuster, D.G.; Bobulescu, I.A.; Zhang, J.; Wade, J.; Moe, O.W. Characterization of the regulation of renal $\mathrm{Na}^{+} / \mathrm{H}^{+}$exchanger NHE3 by insulin. Am. J. Physiol. Renal Physiol. 2007, 292, F577-F585.

69. Wesson, D.E. Endothelin role in kidney Acidification. Semin. Nephrol. 2006, 26, 393-398.

70. Uchida, S. In vivo role of CLC chloride channels in the kidney. Am. J. Physiol. Renal Physiol. 2000, 279, F802-F808.

71. Scheel, O.; Zdebik, A.A.; Lourdel, S.; Jentsch, T.J. Voltage-dependent electrogenic chloride/proton exchange by endosomal CLC proteins. Nature 2005, 436, 424-427.

72. Jentsch, T.J. Chloride transport in the kidney: Lessons from human disease and knockout mice. J. Am. Soc. Nephrol. 2005, 16, 1549-1561.

73. Ceol, M.; Tiralongo, E.; Baelde, H.J.; Vianello, D.; Betto, G.; Marangelli, A.; Bonfante, L.; Valente, M.; Della Barbera, M.; D’Angelo, A.; et al. Involvement of the tubular ClC-type exchanger $\mathrm{ClC}-5$ in glomeruli of human proteinuric nephropathies. PLoS One 2012, 7, e45605:1-e45605:7.

74. Günther, W.; Lüchow, A.; Cluzeaud, F.; Vandewalle, A.; Jentsch, T.J. ClC-5, the chloride channel mutated in Dent's disease, colocalizes with the proton pump in endocytotically active kidney cells. Proc. Natl. Acad. Sci. USA 1998, 95, 8075-8080.

75. Devuyst, O.; Christie, P.T.; Courtoy, P.J.; Beauwens, R.; Thakker, R.V. Intra-renal and subcellular distribution of the human chloride channel, CLC-5, reveals a pathophysiological basis for Dent's disease. Hum. Mol. Genet. 1999, 8, 247-257.

76. Piwon, N.; Günther, W.; Schwake, M.; Bösl, M.R.; Jentsch, T.J. ClC-5 Cl-channel disruption impairs endocytosis in a mouse model for Dent's disease. Nature 2000, 408, 369-373.

77. Hara-Chikuma, M.; Wang, Y.; Guggino, S.E.; Guggino, W.B.; Verkman, A.S. Impaired acidification in early endosomes of ClC-5 deficient proximal tubule. Biochem. Biophys. Res. Commun. 2005, 329, 941-946. 
78. Rickheit, G.; Wartosch, L.; Schaffer, S.; Stobrawa, S.M.; Novarino, G.; Weinert, S.; Jentsch, T.J. Role of $\mathrm{ClC}-5$ in renal endocytosis is unique among $\mathrm{ClC}$ exchangers and does not require PY-motif-dependent ubiquitylation. J. Biol. Chem. 2010, 285, 17595-17603.

79. Reed, A.A.; Loh, N.Y.; Terryn, S.; Lippiat, J.D.; Partridge, C.; Galvanovskis, J.; Williams, S.E.; Jouret, F.; Wu, F.T.; Courtoy, P.J. CLC-5 and KIF3B interact to facilitate CLC-5 plasma membrane expression, endocytosis, and microtubular transport: Relevance to pathophysiology of Dent's disease. Am. J. Physiol. Renal Physiol. 2010, 298, F365-F380.

80. Hryciw, D.H.; Jenkin, K.A.; Simcocks, A.C.; Grinfeld, E.; McAinch, A.J.; Poronnik, P. The interaction between megalin and ClC-5 is scaffolded by the $\mathrm{Na}^{+}-\mathrm{H}^{+}$exchanger regulatory factor 2 (NHERF2) in proximal tubule cells. Int. J. Biochem. Cell Biol. 2012, 44, 815-823.

81. Christensen, E.I.; Devuyst, O.; Dom, G.; Nielsen, R.; Van der Smissen, P.; Verroust, P.; Leruth, M.; Guggino, W.B.; Courtoy, P.J. Loss of chloride channel ClC-5 impairs endocytosis by defective trafficking of megalin and cubilin in kidney proximal tubules. Proc. Natl. Acad. Sci. USA 2003, 100, 8472-8477.

82. Maritzen, T.; Lisi, S.; Botta, R.; Pinchera, A.; Fanelli, G.; Viacava, P.; Marcocci, C.; Marinò, M. ClC-5 does not affect megalin expression and function in the thyroid. Thyroid 2006, 16, 725-730.

83. Wrong, O.M.; Norden, A.G.; Feest, T.G. Dent's disease; a familial proximal renal tubular syndrome with low-molecular-weight proteinuria, hypercalciuria, nephrocalcinosis, metabolic bone disease, progressive renal failure and a marked male predominance. Q.J.M. 1994, 87, 473-493.

84. Lloyd, S.E.; Pearce, S.H.; Fisher, S.E.; Steinmeyer, K.; Schwappach, B.; Scheinman, S.J.; Harding, B.; Bolino, A.; Devoto, M.; Goodyer, P.; et al. A common molecular basis for three inherited kidney stone diseases. Nature 1996, 379, 445-449.

85. Wang, S.S.; Devuyst, O.; Courtoy, P.J.; Wang, X.T.; Wang, H.; Wang, Y.; Thakker, R.V.; Guggino, S.; Guggino, W.B. Mice lacking renal chloride channel, CLC-5, are a model for Dent's disease, a nephrolithiasis disorder associated with defective receptor-mediated endocytosis. Hum. Mol. Genet. 2000, 9, 2937-2945.

86. Devuyst, O.; Jouret, F.; Auzanneau, C.; Courtoy, P.J. Chloride channels and endocytosis: New insights from Dent's disease and ClC-5 knockout mice. Nephron Physiol. 2005, 99, 69-73.

87. Tanuma, A.; Sato, H.; Takeda, T.; Hosojima, M.; Obayashi, H.; Hama, H.; Iino, N.; Hosaka, K.; Kaseda, R.; Imai, N.; et al. Functional characterization of a novel missense CLCN5 mutation causing alterations in proximal tubular endocytic machinery in Dent's disease. Nephron Physiol. 2007, 107, 87-97.

88. Devuyst, O.; Thakker, R.V. Dent's disease. Orphanet. J. Rare Dis. 2010, 5, 28:1-28:8.

89. Addis, M.; Meloni, C.; Tosetto, E.; Ceol, M.; Cristofaro, R.; Melis, M.A.; Vercelloni, P.; Del Prete, D.; Marra, G.; Anglani, F. An atypical Dent's disease phenotype caused by co-inheritance of mutations at CLCN5 and OCRL genes. Eur. J. Hum. Genet. 2013, 21, 687-690.

90. Miyamoto, K.; Tatsumi, S.; Segawa, H.; Ohkido, I.; Takeda, E. Identification and functional analysis of three isoforms for the $\mathrm{Na}^{+}$-dependent phosphate co-transporter (NaPi-2) in rat kidney. Nephrol. Dial. Transplant. 2000, 15, 31-33. 
91. Beck, L.; Karaplis, A.C.; Amizuka, N.; Hewson, A.S.; Ozawa, H.; Tenenhouse, H.S. Targeted inactivation of Npt2 in mice leads to severe renal phosphate wasting, hypercalciuria, and skeletal abnormalities. Proc. Natl. Acad. Sci. USA 1998, 95, 5372-5377.

92. Marks, J.; Debnam, E.S.; Unwin, R.J. Phosphate homeostasis and the renal-gastrointestinal axis. Am. J. Physiol. Renal Physiol. 2010, 299, F285-F296.

93. Hernando, N.; Gisler, S.M.; Pribanic, S.; Deliot, N.; Capuano, P.; Wagner, C.A.; Moe, O.W.; Biber, J.; Murer, H. NaPi-IIa and interacting partners. J. Physiol. 2005, 567, 21-26.

94. Bachmann, S.; Schlichting, U.; Geist, B.; Mutig, K.; Petsch, T.; Bacic, D.; Wagner, C.A.; Kaissling, B.; Biber, J.; Murer, H.; et al. Kidney-specific inactivation of the megalin gene impairs trafficking of renal inorganic sodium phosphate cotransporter (NaPi-IIa). J. Am. Soc. Nephrol. 2004, 15, 892-900.

95. Riquier, A.D.; Lee, D.H.; McDonough, A.A. Renal NHE3 and NaPi2 partition into distinct membrane domains. Am. J. Physiol. Cell Physiol. 2009, 296, C900-C910.

96. Tanimura, A.; Yamada, F.; Saito, A.; Ito, M.; Kimura, T.; Anzai, N.; Horie, D.; Yamamoto, H.; Miyamoto, K.; Taketani, Y.; et al. Analysis of different complexes of type IIa sodium dependent phosphate transporter in rat renal cortex using blue-native polyacrylamide gel electrophoresis. J. Med. Invest. 2011, 58, 140-147.

97. Lanaspa, M.A.; Caldas, Y.A.; Breusegem, S.Y.; Andrés-Hernando, A.; Cicerchi, C.; Levi, M.; Sorribas, V. Inorganic phosphate modulates the expression of the $\mathrm{NaPi}-2 \mathrm{a}$ transporter in the trans-golgi network and the interaction with PIST in the proximal tubule. Biomed. Res. Int. 2013, 2013, 513932:1-513932:9.

98. Gattineni, J.; Bates, C.; Twombley, K.; Dwarakanath, V.; Robinson, M.L.; Goetz, R.; Mohammadi, M.; Baum, M. FGF23 decreases renal NaPi-2a and NaPi-2c expression and induces hypophosphatemia in vivo predominantly via FGF receptor 1. Am. J. Physiol. Renal Physiol. 2009, 297, F282-F291.

99. Roopenian, D.C.; Akilesh, S. FcRn: The neonatal Fc receptor comes of age. Nat. Rev. Immunol. 2007, 7, 715-725.

100. Simister, N.E.; Mostov, K.E. An Fc receptor structurally related to MHC class I antigens. Nature 1989, 337, 184-187.

101. Burmeister, W.P.; Huber, A.H.; Bjorkman, P.J. Crystal structure of the complex of rat neonatal Fc receptor with Fc. Nature 1994, 372, 379-383.

102. Chaudhury, C.; Mehnaz, S.; Robinson, J.M.; Hayton, W.L.; Pearl, D.K.; Roopenian, D.C.; Anderson, C.L. The major histocompatibility complex-related Fc receptor for IgG (FcRn) binds albumin and prolongs its lifespan. J. Exp. Med. 2003, 197, 315-322.

103. Chaudhury, C.; Brooks, C.L.; Carter, D.C.; Robinson, J.M.; Anderson, C.L. Albumin binding to FcRn: Distinct from the FcRn-IgG interaction. Biochemistry 2006, 45, 4983-4990.

104. Nagai, J.; Sato, K.; Yumoto, R.; Takano, M. Megalin/cubilin-mediated uptake of FITC-labeled IgG by OK kidney epithelial cells. Drug Metab. Pharmacokinet. 2011, 26, 474-485.

105. Haymann, J.P.; Levraud, J.P.; Bouet, S.; Kappes, V.; Hagege, J.; Nguyen, G.; Xu, Y.; Rondeau, E.; Sraer, J.D. Characterization and localization of the neonatal Fc receptor in adult human kidney. J. Am. Soc. Nephrol. 2000, 11, 632-639. 
106. Akilesh, S.; Huber, T.B.; Wu, H.; Wang, G.; Hartleben, B.; Kopp, J.B.; Miner, J.H.; Roopenian, D.C.; Unanue, E.R.; Shaw, A.S. Podocytes use FcRn to clear IgG from the glomerular basement membrane. Proc. Natl. Acad. Sci. USA 2008, 105, 967-972.

107. Sarav, M.; Wang, Y.; Hack, B.K.; Chang, A.; Jensen, M.; Bao, L.; Quigg, R.J. Renal FcRn reclaims albumin but facilitates elimination of IgG. J. Am. Soc. Nephrol. 2009, 20, 1941-1952.

108. Tenten, V.; Menzel, S.; Kunter, U.; Sicking, E.M.; van Roeyen, C.R.; Sanden, S.K.; Kaldenbach, M.; Boor, P.; Fuss, A.; Uhlig, S.; et al. Albumin is recycled from the primary urine by tubular transcytosis. J. Am. Soc. Nephrol. 2013, 24, 1966-1980.

109. Christensen, E.I.; Birn, H. Tubular handling of albumin—degradation or salvation? Nat. Rev. Nephrol. 2013, 9, 700-702.

110. Gotthardt, M.; Trommsdorff, M.; Nevitt, M.F.; Shelton, J.; Richardson, J.A.; Stockinger, W.; Nimpf, J.; Herz, J. Interactions of the low density lipoprotein receptor gene family with cytosolic adaptor and scaffold proteins suggest diverse biological functions in cellular communication and signal transduction. J. Biol. Chem. 2000, 275, 25616-25624.

111. Larsson, M.; Hjalm, G.; Sakwe, A.M.; Engstrom, A.; Hoglund, A.S.; Larsson, E.; Robinson, R.C.; Sundberg, C.; Rask, L. Selective interaction of megalin with postsynaptic density-95 (PSD-95)-like membrane-associated guanylate kinase (MAGUK) proteins. Biochem. J. 2003, 373, 381-391.

112. Lou, X.; McQuistan, T.; Orlando, R.A.; Farquhar, M.G. GAIP, GIPC and Galphai3 are concentrated in endocytic compartments of proximal tubule cells: Putative role in regulating megalin's function. J. Am. Soc. Nephrol. 2002, 13, 918-927.

113. Petersen, H.H.; Hilpert, J.; Militz, D.; Zandler, V.; Jacobsen, C.; Roebroek, A.J.; Willnow, T.E. Functional interaction of megalin with the megalin binding protein (MegBP), a novel tetratrico peptide repeat-containing adaptor molecule. J. Cell Sci. 2003, 116, 453-461.

114. Rader, K.; Orlando, R.A.; Lou, X.; Farquhar, M.G. Characterization of ANKRA, a novel ankyrin repeat protein that interacts with the cytoplasmic domain of megalin. J. Am. Soc. Nephrol. 2000, $11,2167-2178$.

115. Chen, W.J.; Goldstein, J.L.; Brown, M.S. NPXY, a sequence often found in cytoplasmic tails, is required for coated pit-mediated internalization of the low density lipoprotein receptor. J. Biol. Chem. 1990, 265, 3116-3123.

116. Nagai, M.; Meerloo, T.; Takeda, T.; Farquhar, M.G. The adaptor protein ARH escorts megalin to and through endosomes. Mol. Biol. Cell. 2003, 14, 4984-4996.

117. Oleinikov, A.V.; Zhao, J.; Makker, S.P. Cytosolic adaptor protein Dab2 is an intracellular ligand of endocytic receptor gp600/megalin. Biochem. J. 2000, 347, 613-621.

118. Traub, L.M. Tickets to ride: Selecting cargo for clathrin-regulated internalization. Nat. Rev. Mol. Cell Biol. 2009, 10, 583-596.

119. Nagai, J.; Christensen, E.I.; Morris, S.M.; Willnow, T.E.; Cooper, J.A.; Nielsen, R. Mutually-dependent localization of megalin and Dab2 in the renal proximal tubule. Am. J. Physiol. Renal Physiol. 2005, 289, F569-F576.

120. Maurer, M.E.; Cooper, J.A. Endocytosis of megalin by visceral endoderm cells requires the Dab2 adaptor protein. J. Cell Sci. 2005, 118, 5345-5355. 
121. Maurer, M.E.; Cooper, J.A. The adaptor protein Dab2 sorts LDL receptors into coated pits independently of AP-2 and ARH. J. Cell Sci. 2006, 119, 4235-4246.

122. Hasson, T. Myosin VI: Two distinct roles in endocytosis. J. Cell Sci. 2003, 116, 3453-3461.

123. Avraham, K.B.; Hasson, T.; Steel, K.P.; Kingsley, D.M.; Russell, L.B.; Mooseker, M.S.; Copeland, N.G.; Jenkins, N.A. The mouse Snell's waltzer deafness gene encodes an unconventional myosin required for structural integrity of inner ear hair cells. Nat. Genet. 1995, $11,369-375$.

124. Hosaka, K.; Takeda, T.; Iino, N.; Hosojima, M.; Sato, H.; Kaseda, R.; Yamamoto, K.; Kobayashi, A.; Gejyo, F.; Saito, A. Megalin and nonmuscle myosin heavy chain IIA interact with the adaptor protein Disabled-2 in proximal tubule cells. Kidney Int. 2009, 75, 1308-1315.

125. Kelley, M.J.; Jawien, W.; Ortel, T.L.; Korczak, J.F. Mutation of MYH9, encoding non-muscle myosin heavy chain A, in May-Hegglin anomaly. Nat. Genet. 2000, 26, 106-108.

126. Seri, M.; Cusano, R.; Gangarossa, S.; Caridi, G.; Bordo, D.; Lo Nigro, C.; Ghiggeri, G.M.; Ravazzolo, R.; Savino, M.; Del Vecchio, M.; et al. Mutations in MYH9 result in the May-Hegglin anomaly, and Fechtner and Sebastian syndromes. The May-Heggllin/Fechtner Syndrome Consortium. Nat. Genet. 2000, 26, 103-105.

127. Seri, M.; Savino, M.; Bordo, D.; Cusano, R.; Rocca, B.; Meloni, I.; Di, B.; Koivisto, P.A.; Bolognesi, M.; Ghiggeri, G.M.; et al. Epstein syndrome: Another renal disorder with mutations in the nonmuscle myosin heavy chain 9 gene. Hum. Genet. 2002, 110, 182-186.

128. Kao, W.H.; Klag, M.J.; Meoni, L.A.; Reich, D.; Berthier-Schaad, Y.; Li, M.; Coresh, J.; Patterson, N.; Tandon, A.; Powe, N.R.; et al. MYH9 is associated with nondiabetic end-stage renal disease in African Americans. Nat. Genet. 2008, 40, 1185-1192.

129. Kopp, J.B.; Smith, M.W.; Nelson, G.W.; Johnson, R.C.; Freedman, B.I.; Bowden, D.W.; Oleksyk, T.; McKenzie, L.M.; Kajiyama, H.; Ahuja, T.S. MYH9 is a major-effect risk gene for focal segmental glomerulosclerosis. Nat. Genet. 2008, 40, 1175-1184.

130. Koral, K.; Erkan, E. PKB/Akt partners with Dab2 in albumin Endocytosis. Am. J. Physiol. Renal Physiol. 2012, 302, F1013-F1024.

131. Garcia, C.K.; Wilund, K.; Arca, M.; Zuliani, G.; Fellin, R.; Maioli, M.; Calandra, S.; Bertolini, S.; Cossu, F.; Grishin, N.; et al. Autosomal recessive hypercholesterolemia caused by mutations in a putative LDL receptor adaptor protein. Science 2001, 292, 1394-1398.

132. Mishra, S.K.; Watkins, S.C.; Traub, L.M. The autosomal recessive hypercholesterolemia (ARH) protein interfaces directly with the clathrin-coat machinery. Proc. Natl. Acad. Sci. USA 2002, 99, 16099-16104.

133. He, G.; Gupta, S.; Michaely, P.; Hobbs, H.H.; Cohen, J.C. ARH is a modular adaptor protein that interacts with the LDL receptor, clathrin and AP-2. J. Biol. Chem. 2002, 277, 44044-44049.

134. Lehtonen, S.; Shah, M.; Nielsen, R.; Iino, N.; Ryan, J.J.; Zhou, H.; Farquhar, M.G. The endocytic adaptor protein ARH associates with motor and centrosomal proteins and is involved in centrosome assembly and cytokinesis. Mol. Biol. Cell. 2008, 19, 2949-2961.

135. Shah, M.; Baterina, O.Y., Jr.; Taupin, V.; Farquhar, M.G. ARH directs megalin to the endocytic recycling compartment to regulate its proteolysis and gene expression. J. Cell. Biol. 2013, 202, $113-127$. 
136. Kang, R.S.; Fölsch, H. ARH cooperates with AP-1B in the exocytosis of LDLR in polarized epithelial cells. J. Cell Biol. 2011, 193, 51-60.

137. Pedersen, G.A.; Chakraborty, S.; Steinhauser, A.L.; Traub, L.M.; Madsen, M. AMN directs endocytosis of the intrinsic factor-vitamin B12 receptor cubam by engaging ARH or Dab2. Traffic 2010, 11, 706-720.

138. Vlassov, A.V.; Magdaleno, S.; Setterquist, R.; Conrad, R. Exosomes: Current knowledge of their composition, biological functions, and diagnostic and therapeutic potentials. Biochim. Biophys. Acta 2012, 1820, 940-948.

139. Théry, C.; Zitvogel, L.; Amigorena, S. Exosomes: Composition, biogenesis and function. Nat. Rev. Immunol. 2002, 2, 569-579.

140. Cocucci, E.; Racchetti, G.; Meldolesi, J. Shedding microvesicles: Artifacts no more. Trends Cell Biol. 2009, 19, 43-51.

141. van Niel, G.; Porto-Carreiro, I.; Simoes, S.; Raposo, G. Exosomes: A common pathway for a specialized function. J. Biochem. 2006, 140, 13-21.

142. Valadi, H.; Ekström, K.; Bossios, A.; Sjöstrand, M.; Lee, J.J.; Lötvall, J.O. Exosome-mediated transfer of mRNAs and microRNAs is a novel mechanism of genetic exchange between cells. Nat. Cell Biol. 2007, 9, 654-659.

143. Lv, L.L.; Cao, Y.; Liu, D.; Xu, M.; Liu, H.; Tang, R.N.; Ma, K.L.; Liu, B.C. Isolation and quantification of microRNAs from urinary exosomes/microvesicles for biomarker discovery. Int. J. Biol. Sci. 2013, 9, 1021-1031.

144. Simpson, R.J.; Lim, J.W.; Moritz, R.L.; Mathivanan, S. Exosomes: Proteomic insights and diagnostic potential. Expert. Rev. Proteomics 2009, 6, 267-283.

145. Pisitkun, T.; Shen, R.F.; Knepper, M.A. Identification and proteomic profiling of exosomes in human urine. Proc. Natl. Acad. Sci. USA 2004, 101, 13368-13373.

146. Gonzales, P.A.; Pisitkun, T.; Hoffert, J.D.; Tchapyjnikov, D.; Star, R.A.; Kleta, R.; Wang, N.S.; Knepper, M.A. Large-scale proteomics and phosphoproteomics of urinary exosomes. J. Am. Soc. Nephrol. 2009, 20, 363-379.

147. Raimondo, F.; Corbetta, S.; Morosi, L.; Chinello, C.; Gianazza, E.; Castoldi, G.; Di Gioia, C.; Bombardi, C.; Stella, A.; Battaglia, C. Urinary exosomes and diabetic nephropathy: A proteomic approach. Mol. Biosyst. 2013, 9, 1139-1146.

148. Russo, L.M.; del Re, E.; Brown, D.; Lin, H.Y. Evidence for a role of transforming growth factor (TGF)-beta1 in the induction of postglomerular albuminuria in diabetic nephropathy: Amelioration by soluble TGF-beta type II receptor. Diabetes 2007, 56, 380-388.

149. Hosojima, M.; Sato, H.; Yamamoto, K.; Kaseda, R.; Soma, T.; Kobayashi, A.; Kabasawa, H.; Takeyama, A.; Ikuyama, K.; et al. Regulation of megalin expression in cultured proximal tubule cells by angiotensin II type $1 \mathrm{~A}$ receptor- and insulin-mediated signaling cross talk. Endocrinology 2009, 150, 871-878.

150. Takeyama, A.; Sato, H.; Soma-Nagae, T.; Kabasawa, H.; Suzuki, A.; Yamamoto-Kabasawa, K.; Hosojima, M.; Kaneko, R.; Higuchi, F.; Kaseda, R.; et al. Megalin is downregulated via LPS-TNF- $\alpha$-ERK1/2 signaling pathway in proximal tubule cells. Biochem. Biophys. Res. Commun. 2011, 407, 108-112. 
151. Cabezas, F.; Lagos, J.; Céspedes, C.; Vio, C.P.; Bronfman, M.; Marzolo, M.P. Megalin/LRP2 expression is induced by peroxisome proliferator-activated receptor -alpha and -gamma: Implications for PPARs' roles in renal function. PLoS One 2011, 6, e16794:1-e16794:17.

152. Reisman, S.A.; Chertow, G.M.; Hebbar, S.; Vaziri, N.D.; Ward, K.W.; Meyer, C.J. Bardoxolone methyl decreases megalin and activates nrf2 in the kidney. J. Am. Soc. Nephrol. 2012, 23, $1663-1673$.

153. Zou, Z.; Chung, B.; Nguyen, T.; Mentone, S.; Thomson, B.; Biemesderfer, D. Linking receptor-mediated endocytosis and cell signaling: Evidence for regulated intramembrane proteolysis of megalin in proximal tubule. J. Biol. Chem. 2004, 279, 34302-34310.

154. Li, Y.; Cong, R.; Biemesderfer, D. The $\mathrm{COOH}$ terminus of megalin regulates gene expression in opossum kidney proximal tubule cells. Am. J. Physiol. Cell Physiol. 2008, 295, C529-C537.

155. Christ, A.; Terryn, S.; Schmidt, V.; Christensen, E.I.; Huska, M.R.; Andrade-Navarro, M.A.; Hubner, N.; Devuyst, O.; Hammes, A.; Willnow, T.E. The soluble intracellular domain of megalin does not affect renal proximal tubular function in vivo. Kidney Int. 2010, 78, 473-477.

156. Motoyoshi, Y.; Matsusaka, T.; Saito, A.; Pastan, I.; Willnow, T.E.; Mizutani, S.; Ichikawa, I. Megalin contributes to the early injury of proximal tubule cells during nonselective proteinuria. Kidney Int. 2008, 74, 1262-1269.

157. Shalamanova, L.; McArdle, F.; Amara, A.B.; Jackson, M.J.; Rustom, R. Albumin overload induces adaptive responses in human proximal tubular cells through oxidative stress but not via angiotensin II type 1 receptor. Am. J. Physiol. Renal Physiol. 2007, 292, F1846-1857.

158. Morigi, M.; Macconi, D.; Zoja, C.; Donadelli, R.; Buelli, S.; Zanchi, C.; Ghilardi, M.; Remuzzi, G. Protein overload-induced NF-kappaB activation in proximal tubular cells requires $\mathrm{H}_{2} \mathrm{O}_{2}$ through a PKC-dependent pathway. J. Am. Soc. Nephrol. 2002, 13, 1179-1189.

159. Burns, W.C.; Kantharidis, P.; Thomas, M.C. The role of tubular epithelial-mesenchymal transition in progressive kidney disease. Cells Tissues Organs 2007, 185, 222-231.

160. Strutz, F.M. EMT and proteinuria as progression factors. Kidney Int. 2009, 75, 475-481.

161. Saito, A.; Takeda, T.; Sato, K.; Hama, H.; Tanuma, A.; Kaseda, R.; Suzuki, Y.; Gejyo, F. Significance of proximal tubular metabolism of advanced glycation end products in kidney diseases. Ann. N. Y. Acad. Sci. 2005, 1043, 637-643.

162. Verbeke, P.; Perichon, M.; Friguet, B.; Bakala, H. Inhibition of nitric oxide synthase activity by early and advanced glycation end products in cultured rabbit proximal tubular epithelial cells. Biochim. Biophys. Acta 2000, 1502, 481-494.

163. Obeid, R.; Shannan, B.; Herrmann, W. Advanced glycation end products overload might explain intracellular cobalamin deficiency in renal dysfunction, diabetes and aging. Med. Hypotheses 2011, 77, 884-848.

164. Sengul, S.; Zwizinski, C.; Batuman, V. Role of MAPK pathways in light chain-induced cytokine production in human proximal tubule cells. Am. J. Physiol. Renal Physiol. 2003, 284, F1245-F1254.

165. Li, M.; Hering-Smith, K.S.; Simon, E.E.; Batuman, V. Myeloma light chains induce epithelial-mesenchymal transition in human renal proximal tubule epithelial cells. Nephrol. Dial. Transplant. 2008, 23, 860-870. 
166. Hutchison, C.A.; Batuman, V.; Behrens, J.; Bridoux, F.; Sirac, C.; Dispenzieri, A.; Herrera, G.A.; Lachmann, H.; Sanders, P.W. International Kidney and Monoclonal Gammopathy Research Group. The pathogenesis and diagnosis of acute kidney injury in multiple myeloma. Nat. Rev. Nephrol. 2011, 8, 43-51.

167. Ogasawara, S.; Hosojima, M.; Kaseda, R.; Kabasawa, H.; Yamamoto-Kabasawa, K.; Kurosawa, H.; Sato, H.; Iino, N.; Takeda, T.; Suzuki, Y.; et al. Significance of urinary full-length and ectodomain forms of megalin in patients with type 2 diabetes. Diabetes Care 2012, 35, 1112-1118.

(C) 2014 by the authors; licensee MDPI, Basel, Switzerland. This article is an open access article distributed under the terms and conditions of the Creative Commons Attribution license (http://creativecommons.org/licenses/by/3.0/). 